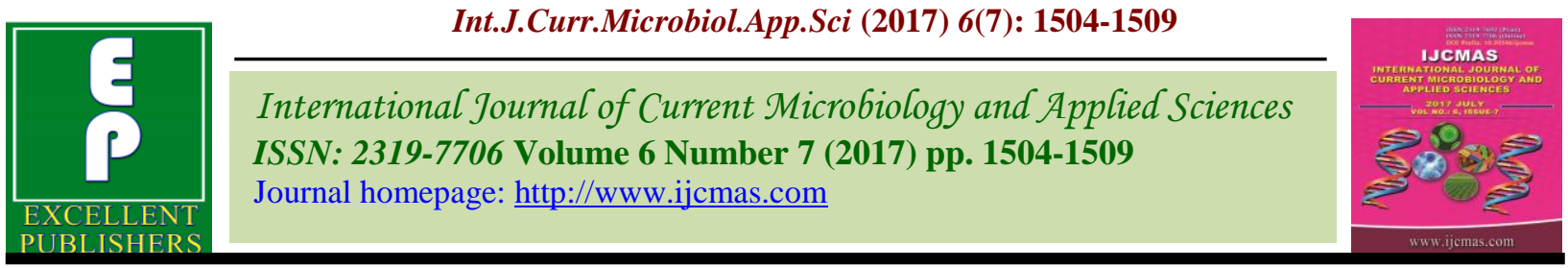

Original Research Article

https://doi.org/10.20546/ijcmas.2017.607.180

\title{
On-farm Assessment of Technological Innovation of Fennel (Foeniculum vulgare mill) Cultivation
}

\author{
Dilip Singh* \\ K.V.K. Bharatpur (Rajasthan), Sri Karan Narendra Agriculture University, Jobner, \\ Jaipur (Rajasthan), India \\ *Corresponding author
}

\section{A B S T R A C T}

\begin{tabular}{|l|}
\hline Ke y w o r d s \\
Front line \\
Demonstration, \\
Fennel \\
technologies and \\
Farmers practices. \\
\hline Article Info \\
\hline $\begin{array}{l}\text { Accepted: } \\
\text { 19 June } 2017 \\
\text { Available Online: } \\
\text { 10 July } 2017\end{array}$ \\
\hline
\end{tabular}

\section{Introduction}

India is well-known as "Land of Spices" across the world since long back. We have been cultivating these precious spices for fulfilling our various needs since ages. Our ancestors have been using these spices for adding taste and flavour in edibles and beverages. These spices possess many medicinal properties. Fennel (Foeniculum vulgare mill) is one of the most important seed spice crops grown in India.
The plants are annual, biennial or perennial aromatic herb. Fennel seeds are aromatic with a pleasant taste and widely used for flavouring and garnishing material in culinary preparation. It is also used for chewing. Fennel is used against the diseases like cholera, biliousness, dysentery, diarrhea, cough, cold, constipation. They are used against diseases affecting chest, spleen, kidney and cure of cholic pain. Seeds are rich 
in protein $(9.5 \%)$, minerals $(13.4 \%)$ and vitamins such as vitamin $\mathrm{A}, \mathrm{C}$, Thiamin, Riboflavin, and Niacin. The seeds contain essential oil, which is used as flavouring agent in manufacturing of pickles, cakes perfumes, soap, liquors and cough drop. Its seeds contain 0.7 to $1.9 \%$ volatile oil. The chief constituent of oil is an ethole (50-70\%). The volatile oil is used for manufacturing cordials and fennel water which is given to infants as medicine. Fennel and its oil both stimulate aromatic and stop flatulence. Its decoction is given to women for blood purification and uterus clearing. It requires dry and cool climate for better seed production with quality. It is susceptible to frost particularly at flowering stage. It can be grown on wide varieties of soil (except sandy soil). A well-drained loamy and black cotton soil containing lime is preferred (Singh and Singh, 2015). India is the largest producer of fennel which is cultivated in 0.99 lakh hectare with a production of 1.43 lakh tonnes and productivity of $17.1 \mathrm{q} / \mathrm{ha}$.) With the $7.20 \%$ share in area and $11.82 \%$ share in production of seed spices during 2012-13 (Anonymous 2015). The fennel seeds were exported to the tune of 17300 tonnes values worth Rs.16001 lakh with the $6.82 \%$ share in quantity and $6.51 \%$ share in values of seed spices exported from India during 2013-14 (Spices Board of India, Anonymous, 2015). The major markets for export are U.S.A., U.K., U.A.E., South Africa, Malaysia etc. Rajasthan and Gujarat are also known as 'Seed Spices Bowl' and contributes more than $80 \%$ of the total seed spices produced in India. Rajasthan is the second largest producer of fennel after Gujarat. Rajasthan produced 14277 tonnes fennel from 15161 ha area during 2013-14. But the average productivity of fennel crop $(942 \mathrm{~kg} / \mathrm{ha})$ in the Rajasthan is very low as compared to other parts of the country (Anonymous, 2015). Fennel producing other states are Madhya Pradesh, Haryana, Punjab and Uttar Pradesh. In Rajasthan major fennel growing districts are Tonk, Sirohi Jodhpur, Ajmer, Udaipur, Pali, Sawai Madhopur and Bharatpur. India is exporting only $10.80 \%$ of its seed spice production. Keeping this in view, seed spices are considered not only cash crops but also they can be termed as "dynamic crop commodities" particularly in the view of their great export potential. Therefore, there is an emerging need not only to increase the productivity but also to improve the quality and other related parameters for gaining more foreign exchange to the national wealth. The shift or increase in average productivity has remained low for seed spices crop like fennel mainly due to lack of sufficient number of improved varieties suitable for different regions with higher yield, resistant to different biotic and abiotic stresses with better quality attributes. Therefore, improved varieties with desired attributes are the need of the day. Both National Research Centre on Seed Spices, Tabiji, Ajmer and Sri Karan Narendra Agriculture University Jobner-Jaipur have done remarkable work in the direction of variety and agro-Technique development of various seed spices crops. This is a great challenge for as other country like Egypt for fennel is competing with higher yield per unit area. Most of the seed spices are severely damaged by soil borne fungus like Fusarium or Pythium. If the farmers are going for deep summer ploughing in the month of May or June or if they are using the soil solarisation process then we can certainly reduce the acute problem of wilt and other soil borne fungus, additionally solarisation reduces the weed populations by deactivating the weed seed bank in the soil. For solarisation transparent plastic sheet probably having thickness of 2025 micron is used at least for a period of three weeks during May or June. Similarly twothree ploughing upto 30-40 centimeter are effective for reducing the incidence of wilt during the ensuing season of its cultivation. Integrated approach taking into account 
degradable chemicals and bio-agents is very much required to raise a healthy crop with required standards. Therefore, a proper standardization of available Integrated Pest Management and Integrated Disease Management packages is needed that can be made readily available to farmers for increasing our export potential. Hence, an IPM and IDM programme should involve a bio-intensive approach including sanitation, mechanical barriers, scouting, GAP (Good Agricultural Practices) protocols, biocontrol and selected pesticides whenever necessary. India has its own GAP Standards formulated in the year 2011 namely "India GAP-2011" which covers all the crops and commodities for their safe cultivation, handling and consumption (Singh et al., 2013).

The main objective of FLDs are to demonstrate newly released crop production and protection technologies and it's management practices in the farmer's fields under different agro-climatic regions and farming situations like high yielding varieties, seed treatment, timely sowing, spacing, weed management nutrient management, pest and disease management etc. among the farmers accompanied with organizing extension programmes (field day) for horizontal dissemination of the technologies. While demonstrating the technologies in the farmers field, the scientist are required to study the factor contributing higher crop production, field constraints of production and thereby generate production data and feedback information. FLDs are conducted under the close supervision of scientists of the National Agricultural Research System comprising of ICAR Institute, National Research Centers, Project Directorates, Krishi Vigyan Kendras and State Agricultural Universities and its regional research stations. If there is facility of irrigation then fennel crop is proving more profitable than other traditional crops like mustard and wheat. There is no damage by stray animals (a major problem now a day), higher yield potential and attractive market price is encouraging farmers to adopt fennel cultivation to increase their socio economic condition. There is lot of scope of fennel growing in winter season under assured irrigation facility.

FLDs are organized in a block of 2 to 5 hectares involving all those farmers whose plots fall in the identified demonstration block. Only critical inputs and training are provided from the scheme budget, remaining inputs are supplied by the farmers themselves. The purpose is to convince extension functionaries and farmers together about the potentialities of the technologies for further wide scale diffusion. Front Line demonstration are used as a source of generating data on factors contributing higher crop yield and constraints of production under various farming situation. The present study was carried for on-farm assessment of technological innovation of fennel cultivation.

\section{Materials and Methods}

This study was conducted during the year 2016-17 under the Scheme Mission for Integrated Development of Horticulture (MIDH). A total of 28 farmers from different categories were selected purposively from adopted one village Pana (Bayana) of Bharatpur district of Rajasthan for conducting frontline demonstrations on their field (14 ha area). Bharatpur District of Rajasthan comes in Agro-climatic zone of Rajasthan III B Flood Prone Eastern Plain. Here, generally in winter's minimum temperature goes to $2-3^{\circ} \mathrm{C}$ and in summer maximum temp. Reaches to $47^{\circ} \mathrm{C}$, annual rainfall is $600-650 \mathrm{~mm}$ per year. The study comprised of four high yielding fennel varieties viz., RF-205, RF-125, RF-145 and RF-101 (developed by the SKNAU Jobner-Jaipur) with the recommended package of practices. Sowing was done in the 
last week of October, while harvesting in the second week of April. Fertilizer schedule was $\mathrm{N}: 90, \mathrm{P}_{2} \mathrm{O}_{5}: 40, \mathrm{~K}_{2} \mathrm{O}: 0 \mathrm{~kg} / \mathrm{ha}$ for all the varieties. The need based plant protection chemicals were used to control the insectpests. Locally cultivated variety procured from private sector as practiced by the farmers with their own management system was taken as local check. In the present study the data were collected through personal interviews, group discussion and empirical observations with the help of semi-structured interview schedule and field record of Front Line Demonstration plots and farmers practices. To estimate the technology gap, extension gap and technology index, the following formula were used after Samui et al., (2000) and Sagar and Chandra (2004).

Technology gap: Potential YieldDemonstration yield

Extension gap: Demonstration yield-Farmers yield

Technology index: [(Potential yieldDemonstration yield) / Potential yield] X 100

\section{Results and Discussion}

The potential and field performance of the newly, released fennel varieties along with the local check were evaluated and data are presented in table 1 . The percentage increase in the seed yield over the farmers practice was 10.95, 14.08, 17.41 and 18.41 for RF-205, RF-101, RF-145 and RF-125 respectively.

The technology gap was large that ranged from $1.20 \mathrm{q} / \mathrm{ha}$ for $\mathrm{RF}-125$ to $2.70 \mathrm{q} / \mathrm{ha}$ for RF- 205, which corroborates to the gap in demonstrated yield over potential yield. The technology gap observed may be attributed to variation in the soil fertility, weather conditions and implementation of management practices. Though the technology among the varieties did not vary widely, development of location specific technology appears to be necessary to achieve the expected yields from different fennel varieties. RF-205, RF-101, RF-145 and RF125 showed the technology gap of 2.70, 1.07 $\mathrm{q} / \mathrm{ha}, 1.40 \mathrm{q} / \mathrm{ha}$ and $1.20 \mathrm{q} / \mathrm{ha}$ respectively, which need some more efforts from the extension agencies to bridge the gap.

Comparatively higher extension gap (3.70 $\mathrm{q} / \mathrm{ha}$ ) was recorded for variety RF-125, followed by RF-145 (3.50q/ha), RF-101(2.83 $\mathrm{q} / \mathrm{ha})$ and RF-205 (2.20 q/ha). It is indicated that there is need to educate the farmers through various means for optimizing the seed yield by adopting the improved fennel technology practices as technology gap is realizable under on-farm conditions. More use of newly released high yielding varieties by the farmers will subsequently change existing trend of extension gap as to reverse. The new technology will eventually motivate the farmers to adopt the promising technology with use of proper management practices for increasing the profitability. The technology index shows the feasibility of the evolved technology at the farmer's field. The lower value of technology index more is the feasibility of the technology. The technology index of variety RF-101 (4.46\%) is closely followed by RF-125 (4.80\%). The higher technology index of variety RF-205 (10.80\%) and RF-145 (5.60\%) indicate existence of a considerable gap between the technology performance at research station and the farmer's field. The technology index of three fennel varieties RF-101, RF-125 and RF-145 point that these varieties are performing quite well in the irrigated condition of Flood Prone Eastern Plain Zone 3B of Rajasthan and will help to increase the productivity of fennel in this area through the adoption of improved practices. The findings are in line with the findings of Meena and Singh (2011). 
Table.1 Productivity of fennel variety, yield gap and technology index

\begin{tabular}{|l|l|l|l|l|l|l|l|l|l|}
\hline Variety & $\begin{array}{l}\text { No. } \\
\text { FLDs }\end{array}$ & $\begin{array}{l}\text { Area } \\
\text { (ha) }\end{array}$ & $\begin{array}{l}\text { Potential } \\
\text { yield } \\
\text { (q/ha) }\end{array}$ & $\begin{array}{l}\text { FLD } \\
\text { Yield } \\
\text { (q/ha) }\end{array}$ & $\begin{array}{l}\text { Local } \\
\text { check } \\
\text { yield } \\
\text { (q/ha) }\end{array}$ & $\begin{array}{l}\text { \% increase } \\
\text { over local } \\
\text { check }\end{array}$ & $\begin{array}{l}\text { Technology } \\
\text { Gap } \\
\text { (q/ha) }\end{array}$ & $\begin{array}{l}\text { Extension } \\
\text { gap } \\
\text { (q/ha) }\end{array}$ & $\begin{array}{l}\text { Technology } \\
\text { Index (\%) }\end{array}$ \\
\hline RF-205 & 2 & 1 & 25 & 22.30 & 20.10 & 10.95 & 2.70 & 2.20 & 10.80 \\
\hline RF-101 & 8 & 4 & 24 & 22.93 & 20.10 & 14.08 & 1.07 & 2.83 & 4.46 \\
\hline RF-145 & 2 & 1 & 25 & 23.60 & 20.10 & 17.41 & 1.40 & 3.50 & 5.60 \\
\hline RF-125 & 16 & 8 & 25 & 23.80 & 20.10 & 18.41 & 1.20 & 3.70 & 4.80 \\
\hline
\end{tabular}

Table.2 Economics of cultivation of fennel

\begin{tabular}{|l|l|l|l|l|l|l|l|l|}
\hline $\begin{array}{l}\text { Sl.N } \\
\text { o. }\end{array}$ & Variety & $\begin{array}{l}\text { Yield } \\
\text { q/ha }\end{array}$ & $\begin{array}{l}\text { Cost of } \\
\text { cultivation } \\
\text { (Rs/.ha) }\end{array}$ & $\begin{array}{l}\text { Gross } \\
\text { return } \\
\text { (Rs/ha) }\end{array}$ & $\begin{array}{l}\text { Net } \\
\text { return } \\
\text { (Rs./ha) }\end{array}$ & $\begin{array}{l}\text { B:C } \\
\text { ratio }\end{array}$ & $\begin{array}{l}\text { \% of } \\
\text { additional } \\
\text { yield over } \\
\text { FP (q/ha) }\end{array}$ & $\begin{array}{l}\text { Additional } \\
\text { return over } \\
\text { FP (Rs./ha) }\end{array}$ \\
\hline 1 & RF-205 & 22.30 & 26000 & 133800 & 107800 & $1: 5.15$ & 10.95 & 11600 \\
\hline 2 & RF-101 & 22.93 & 26000 & 137580 & 111580 & $1: 5.29$ & 14.08 & 15380 \\
\hline 3 & RF-145 & 23.60 & 26000 & 141600 & 115600 & $1: 5.45$ & 17.41 & 19400 \\
\hline 4 & RF-125 & 23.8 & 26000 & 142800 & 116800 & $1: 5.49$ & 18.41 & 20600 \\
\hline & Average & 23.16 & 26000 & 138960 & 112960 & $1: 5.34$ & 15.22 & 16760 \\
\hline 5 & $\begin{array}{l}\text { Local } \\
\text { (Farmers } \\
\text { practices) } \\
\text { check }\end{array}$ & 20.10 & 25000 & 120600 & 95600 & $1: 4.82$ & - & - \\
\hline
\end{tabular}

\section{Economics of the front line demonstrations}

It is important to know the economical yard stick of the demonstrated fennel technology as compared to the existing practices of the farmers. All the input-output cost data, except fixed cost were recorded during the season and analyzed. The comparative benefit cost analysis data are presented in table 2. The highest net return was obtained from RF-125 variety (Rs. 116800/ha) followed by RF-145 (Rs. 115600/ha), RF-101(Rs.111580/ha), RF205 (Rs. 107800/ha), and Local check (Rs.95600/ha). Average cost of cultivation per hectare was Rs. 26000, giving a net return of Rs.112960 per ha due to high price of the seed in year 2017, which was about Rs.6000 per quintal. In terms of benefit-cost ratio, the variety RF-125 ranked first (5.49) followed by RF-145 (5.45), RF-101 (5.29), RF-205 (5.15), Average of all varieties (5.34) and Local check (4.82).

The Local Check did not give comparatively encouraging results in terms of benefit cost and net return. Variety-wise comparison of additional gain showed that the demonstrated improved varieties gave more yield under FLDs that ranged from 10.95 per cent from the variety RF-205 to 18.41 per cent from the variety RF-125 over farmers' practice. Besides that, the additional economic return obtained ranged from Rs. 11600/ha from the variety RF-205 to Rs./ha 20600 from the variety RF-125.Abovedata showed that the RF-125 gave more benefit due to more yield as the variety is well fitted under the agroclimatic conditions. The findings are 
confirmed with the findings of Khan et al., (2010), Meena et al., (2010) and Singh et al., (2011).

In conclusion, under diversified agro-climatic conditions, three varieties of fennel viz., AF1, RF-205 and RF-125 have given encouraging results over local check and have potential to perform well with timely management practices in arid condition of Rajasthan. These varieties may be popularized with full package of practices to explore the potential in field conditions and mitigate the extension gap simultaneously efforts need to be made to reduce the large technology gap described in this paper. In economic view, an additional cost mainly for inputs was increased slightly in FLDs over local check. However, it was recovered by increasing gross and net return substantially and resulted in more benefits cost ratio than the local check. The use of latest production technologies with timely systematic management would increase productivity of fennel and income of the small and marginal farmers who are mainly associated with this crop. There is need to implement multi-pronged strategy, which includes vertical and horizontal productivity growth through better adoption.

\section{References}

Anonymous 2015.Annual progress Report 201415 , Item wise export of spices from India (2013-14). National Research Center on Seed Spices, Ajmer. Annexture II pp 97.

Anonymous 2015.Annual progress Report 201415, Seed Spices Area and Production (2012-13).National Research Center on
Seed Spices, Ajmer. Annexture II pp 97. Anonymous 2015. Major spices/State wise area and production of spices, Spices Board of India, Ministry of commerce and Industry, Govt. of India, pp1-3.

Khan, M.A., Mehta, R.S.; Aishwath, O.P. and Anwer, M.M. 2010. Growing seed spices for more foreign exchange. Indian Horticulture, 55 (4): 11-12.

Meena, S.S., Lal, G.; Mehta, R.S.; Kant, K. And Anwer, M.M. 2010. Seed spices for home remedies. Indian Horticulture, 55 (4): 6-8.

Meena, M.L. and Singh, D 2011. Impact of front line demonstrations on yield of cumin in arid zone of Rajasthan. International J. Seed Spices 1 (1):77-80.

Sagar, R.L. and Chandra, G. 2004. Evaluation of Front Line Demonstration on Mustard in

Sunderban, West Bengal. Indian Journal of Extension Education, XXXX, (3\&4):96-97.

Samui, S.K. Maitra, S., Roy, D.K. Mondal, A.K. and Saha, D., 2000. Evaluation on front line demonstration on groundnut (Arachis hypogea L). J Indian Soc. Coastal Agric. Res., 18:180- 183.

Singh, D., Meena, M.L. and Chaudhary, M.K. 2011. Boosting seed spices production technology through front line demonstrations. International J. Seed Spices 1 (1):81-84.

Singh, Balraj, Singh, Ravindra and Solanki, R.K. 2013.Adoption of modern techniques for increasing productivity and quality in seed spices. Souvenir, National Seminar on Production, Productivity and Quality of Spice (2-3 February, 2013) souvenir. National Research Center on Seed

Spices. Ajmer Pp 72-83

Singh I.S. and Singh Vinod 2015.Production, Handling and Processing of Spices. Westville publishing House, New Delhi.

\section{How to cite this article:}

Dilip Singh. 2017. On-farm Assessment of Technological Innovation of Fennel (Foeniculum vulgare mill) Cultivation. Int.J.Curr.Microbiol.App.Sci. 6(7): 1504-1509.

doi: https://doi.org/10.20546/ijcmas.2017.607.180 